\title{
On Governance, Embedding and Marketing: Reflections on the Construction of Alternative Sustainable Food Networks
}

\author{
Dirk Roep · Johannes S. C. Wiskerke
}

Accepted: 8 July 2010/Published online: 1 August 2010

(C) The Author(s) 2010. This article is published with open access at Springerlink.com

\begin{abstract}
Based on the reconstruction of the development of 14 food supply chain initiatives in 7 European countries, we developed a conceptual framework that demonstrates that the process of increasing the sustainability of food supply chains is rooted in strategic choices regarding governance, embedding, and marketing and in the coordination of these three dimensions that are inextricably interrelated. The framework also shows that when seeking to further develop an initiative (e.g., through scaling up or product diversification) these interrelations need continuous rebalancing. We argue that the framework can serve different purposes: it can be used as an analytical tool by researchers studying food supply chain dynamics, as a policy tool by policymakers that want to support the development of sustainable food supply chains, and as a reflexive tool by practitioners and their advisors to help them to position themselves, develop a clear strategy, find the right allies, develop their skills, and build the capacities that they need. In this paper, we elaborate upon the latter function of the framework and illustrate this briefly with empirical evidence from three of the initiatives that we studied.
\end{abstract}

Keywords Food supply chain - Governance $\cdot$ Embedding $\cdot$ Marketing $\cdot$ Reflexive tool

\section{Introduction}

During the last two decades, the agro-food sector in Europe has undergone profound changes (Sonnino and Marsden 2006). On the one hand we are witnessing processes of globalization of the agro-food chain, the industrialization of food production, and

D. Roep $(\bowtie)$. J. S. C. Wiskerke

Wageningen University, Rural Sociology Group,

Hollandseweg 1, $6707 \mathrm{KN}$ Wageningen, The Netherlands

e-mail: dirk.roep@wur.nl 
economic concentration in the processing industry and retail sectors (Kirwan et al. 2004). On the other hand, one can observe the emergence of a wide variety of new food networks (in some cases these are more a re-emergence of traditional, authentic artisanal networks) that are characterized by notions of re-localization, embeddedness, and a turn to quality (Renting et al. 2003; Watts et al. 2005). The increase in the number and kinds of new food networks is generally understood as a part of a wider social movement countering the various unsustainabilities evoked by prevailing food regimes of global systems of food provision (Marsden et al. 1999; Lang 2010; Van der Ploeg 2010). Alternative food networks (AFNs) distinguish themselves from these global food regimes by building new producers-consumer alliances and creating experimental spaces to develop novel practices of food provision that are more in tune with their values, norms, needs, and desires, that built on the reproduction and revaluation of local sources, and that result in food of distinct and better appreciated qualities. In AFNs food is reconnected to the social, cultural, and environmental particularities of the context or the "local" in which it is produced (Kirwan 2004).

Creating distinctiveness and effectively reforming (Roep and Wiskerke 2004) the production-consumption patterns of the prevailing food regime is, however, easier said than done. Regardless of whether it involves the creation of a new food supply chain or the radical transformation of an existing one, these dynamics are complex given the multi-actor, multi-aspect, and multi-level character of transformation processes in the agro-food system (Wiskerke and Van der Ploeg 2004).

In this paper, ${ }^{1}$ we attempt to come to grips with the complexity of agro-food transformation processes by presenting an empirically grounded framework into the creation and development of alternative and by the intentions of its initiators also more sustainable food supply chains. In the next section we will present this framework and explain its constituting dimensions. After that we will elaborate upon this conceptual framework as a reflexive tool by showing how it can be used at different critical moments in the construction and development of a food supply chain: at the start, in the process of scaling up and in the process of product diversification. We end this article with several concluding remarks.

\section{Constructing Distinctiveness: Introducing the GEM-Framework}

This paper is based upon the results of SUS-CHAIN, an EU-funded research project entitled about the potential role of new food supply chains in sustainable rural development. SUS-CHAIN was undertaken as response to the growing emergence of issues of food quality and sustainable rural development as central concerns in discourses over the future of food and farming in Europe. The project ran from 2003 to 2006 and was carried out by a multi-disciplinary team of sociologists, economists, and marketing experts from seven leading European universities paired with NGOs active in the field of sustainable food provision and marketing (see www.sus-chain.org for details of the project and the project consortium).

\footnotetext{
${ }^{1}$ This paper is an elaboration of the paper we presented at the 2007 EURSAFE conference in Vienna. For the extended summary of that conference paper see Roep and Wiskerke (2007).
} 


\section{A Few Notes on the Research Methodology}

As part of this project the start and evolution of fourteen food supply chain initiatives in seven European countries were reconstructed (see Table 1 for an overview of the initiatives). The synchronic, detailed reconstructions of the creation, development and working of these fourteen initiatives were methodologically inspired by Actor-Network Theory (ANT). "Actor network theory is a disparate family of material-semiotic tools, sensibilities, and methods of analysis that treat everything in the social and natural worlds as a continuously generated effect of the webs of relations within which they are located. It assumes that nothing has reality or form outside the enactment of those relations. Its studies explore and characterize the webs and the practices that carry them. Like other material-semiotic approaches, the actor network approach thus describes the enactment of materially and discursively heterogeneous relations that produce and reshuffle all kinds of actors including objects, subjects, human beings, machines, animals, "nature," ideas, organizations, inequalities, scale and sizes, and geographical arrangements" (Law 2009, p. 141). As Fenwick (2010, p. 110) concludes, comparing three socio-material approaches: "ANT studies are particularly useful for tracing the ways that things come together. It can show how things are invited or excluded, how some linkages work and others do not, and how connections are bolstered to make themselves stable and durable by linking to other networks and things." The use of ANT in

Table 1 SUS-CHAIN food supply chain initiatives

\begin{tabular}{ll}
\hline Country & Initiative \\
\hline The Netherlands & De Hoeve (newly created supply chain for certified pork) \\
& Beemsterkaas (cheese marketed under regional brand name by CONO, \\
& a dairy farmers co-operative) \\
Cornwall Food Programme (localizing food procurement by the National & Health Service hospitals in Cornwall) \\
United Kingdom & COOP local sourcing initiative (procurement of local food by supermarkets \\
& in South East England) \\
Pain de seigle du Valais AOC (PDO certified rye bread) & NaturaBeef (supply of certified beef at national scale) \\
Cooperativa Agricola Firenzuola (creating a national supply chain \\
for organic beef) \\
Pecorino di Pistoia (raw milk sheep cheese from the Pistoia mountains) \\
Biomelk Vlaanderen (organic milk in Flanders) \\
Westhoek Hoeve Producten (marketing of on-farm processed products \\
from the Westhoek region) \\
Latvian Association of beef cattle breeders (improvement and promotion \\
of Latvian beef) \\
Rankas Piens (dairy supply chain in Ranka) \\
Upländer Bauernmolkerei (production and marketing of regional dairy \\
products) \\
Tegut - Rhöngut (supermarket's initiative for production, processing and \\
marketing of regional organic meat products) \\
Latvia
\end{tabular}


agro-food studies is relatively new as compared to, for instance, political economy (Murdoch et al. 2000). Yet, its value for describing and analyzing contemporary reconfiguration processes in the agro-food sector is increasingly acknowledged by different authors (Murdoch 2000; Goodman and DuPuis 2002). Actor-networks are seen as assemblages of heterogeneous entities, of human as well as non-human nature (Callon 1986), where the relations constitute the entities and where the nature of the relations determine the stability and durability of the actor-network. Understanding the emergence, evolution, and durability of agro-food networks thus implies an endeavor to examine dynamically "all linkages between all the enrolled entities" (Murdoch 2000, p. 410).

Central questions are how AFNs are forged, developed, extended and become stable, how resistance is overcome, and how actor-network effects such as power, fame, size, scope or organization are generated? (Law 1992). Actor-networks evolve in translation cycles in which entities get shaped and reshaped as a result of their enrolment in an actor-network (Callon 1986). In SUS-CHAIN subsequent translation cycles are reconstructed in case studies (Brunori and Wiskerke 2004) to be able to identify in retrospect determining changes in the transformation of existing or the emergence of new food supply chains. These complex, interrelated changes are framed along three main dimensions.

\section{Towards a Conceptual Framework}

The fourteen initiatives that we studied represent an impressive diversity with regard to the initiators, their intentions, capacities, and strategies, the configuration of the food supply chain, the problems addressed, the goals pursued, the public support received and needed, their level of success, and their impact on rural development. However, a comparative analysis of the fourteen initiatives also revealed some striking communalities regarding the dimensions through which distinctiveness is created and realized:

1. Governance. This involves both structural as well as process-related aspects of creating, maintaining, and transforming a food network (Berger 2003):

(a) The governance structure, i.e., the way in which the alliance is organized (e.g., open group, club, "channel captain" or firm), its wider network (e.g., the kind of societal organizations and interest groups, if any, that are involved in strategic development and decision making) and its legal or formal status (e.g., association, cooperative, public-private partnership, limited company, et cetera).

(b) The governance process, i.e., the way in which the food alliance and network is governed. This includes issues such as the division of roles, decision making procedures, power relationships within the network, contractual arrangements, codes of practice, style of governance (e.g., command and control or consultation, negotiation, and consensus building), et cetera.

2. Embedding. The concept of "embeddedness" was originally based upon the idea that economic systems, such as a food supply chain, operate within a 
network of relationships, institutional arrangements, and cultural meanings that limit the extent to which economic actors can be regarded as purely instrumentally and rational in their market orientation (Granovetter 1985). Over recent decades this concept has gradually taken on a more specific connotation within the domain of agro-food studies (see e.g., Sonnino 2007; Sonnino and Marsden 2006). Hess (2004) distinguishes societal, network, and territorial embeddedness, but seems to overlook what is rather obvious in agriculture and food production: the embedding in socio-material resources such as soil or animal breeds that differ between different "locales" as a result from the different articulation or co-production of natural and social ordering processes. Van der Ploeg (2006) argues that the regrounding of food production in its particular agro-ecological setting is key to sustainability, next to reembedding in (local) community and wider society. In the SUS-CHAIN these multiple dimension of embeddedness are taken into account as: (a) the extent to which food supply chains use local resources (e.g., soil, breeds, skills and knowledge, processing units, retail outlets); (b) the extend to which local actors and stakeholder organizations are involved, and (c) the extent to which the values, codes, and rules that represent the food product and the chain through which it is produced are shared by the wider network of stakeholders, consumers, and society in general (e.g., values as environmental friendliness, food miles, animal welfare, fair trade, and health).

3. Marketing. Marketing refers to the market oriented business management of an enterprise or alliance. It relates business to its environment. An analysis of markets and consumers is translated into objectives and a marketing strategy which is then operationalized. Marketing is more than just "putting a product on the market," "enhancing sales," or "advertising." It has become an integral part of the management of an enterprise or alliance (Schaer and Sirieix forthcoming). The marketing success of an enterprise or alliance depends on its capacity to continually understand, anticipate, and adapt to market developments and the consumers in particular. Since the 1960s, most industry sectors have included marketing theory in their management philosophy, the food sector being among the last ones to follow this development. Within marketing management two spheres of strategic and operational marketing are distinguished (Schaer 2001) that are interconnected and need ongoing coordination (Schaer and Sirieix forthcoming):

(a) Strategic marketing entails the explication of objectives and formation of a marketing plan based on an analysis of the market, the consumers, and the environment resulting in, e.g., market differentiation, consumer targeting, the market share aimed for, but this might also include ethical, social, or ecological codes.

(b) Operational marketing deals with the implementation of the marketing plan, applying the best mix of policies and instruments also known as implementation of the "marketing mix" of price, product, place (distribution), and public relation or communication 


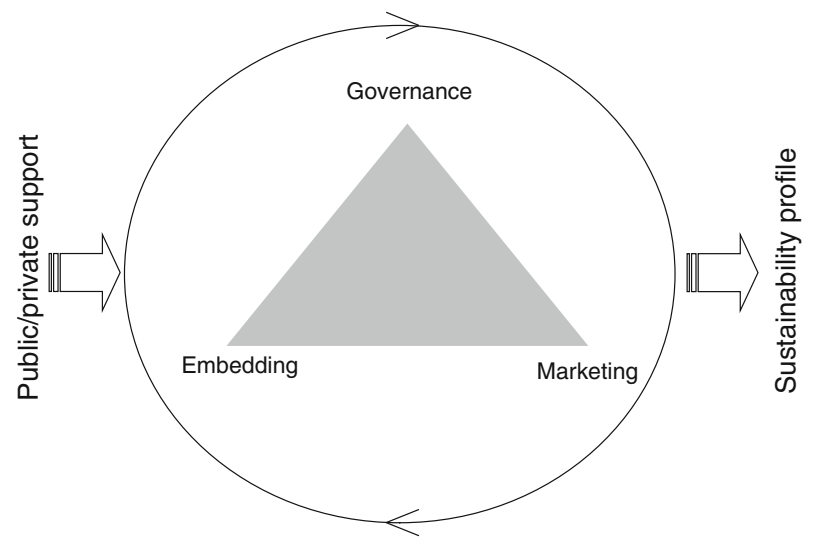

Fig. 1 Conceptual framework (Source: Roep and Wiskerke 2006)

Constructing a new food supply chain always involves making conscious and strategic choices over governance, embedding, and marketing and co-ordinating these three dimensions. Transforming an existing food supply chain will involve rethinking, reassessing, and reconfiguring these dimensions. These three dimensions are interrelated and interconnected, as shown in the triangle in Fig. 1. When scaling up a food supply chain these have to be continuously coordinated and rebalanced. In Fig. 1 this process is represented by the circle with arrows. The conceptual framework shown in this figure also demonstrates that the performance of a food supply chain, as established with various sustainability indicators, reflects the particular art of balancing between governance, embedding, and marketing activities in a FSC, resulting in a specific sustainability profile. It also illustrates that public and/or private support can to be targeted the specific aims and needs to further strengthen a FSC's sustainability performance. ${ }^{2}$

\section{The Art of Balancing Governance, Embedding, and Marketing}

Initiators of new food supply chains usually lack the required experience and expertise for continuous evaluation and reflection. They are often too dedicated and too deeply involved to distance themselves from their own practices and to learn from the success and failures of other initiatives. As a result they might run into the usual pitfalls, overlook options, develop blind spots, or get locked in. And although learning by doing will remain essential to the shop floor, including the less joyful lessons, the learning by doing performance can be elevated by self-reflection and reflection on other initiatives. Here external advisors can come in and offer additional support to practitioners by jointly evaluating and reflecting on their practices and by mirroring themselves against other initiatives, ultimately to be

\footnotetext{
${ }^{2}$ In Roep and Wiskerke (2006) the sustainability profiles of 14 supply chains are presented and briefly discussed. Likewise the private and/or public support received by each initiative is described and briefly assessed.
} 
better equipped to decide on how to proceed. These advisors and consultants can use the Governance-Embedding-Marketing framework (hereafter referred to as GEMframework) as a tool to highlight the importance of and reflect on a "proper" balancing of governance, embedding, and marketing in the construction of a food supply chain. Apart from knowing how to facilitate joint learning and reflection among practitioners, these external advisors need to have expertise on a wide repertoire of food supply chain initiatives as well as substantial capacity to facilitate joint learning and reflection.

We will now illustrate how joint learning and self-reflection by practitioners with regard to the proper balancing of governance, embedding, and marketing can benefit from lessons learned in other initiatives. For this purpose, we selected three cases that represent well the different crucial moments of rebalancing in the evolution of a FSC (see Table 1 for a brief overview of the initiatives):

1. The start of a food supply chain, illustrated by the Dutch initiative of De Hoeve;

2. The scaling up of a food supply chain, illustrated by the Swiss initiative of NaturaBeef;

3. The diversification of a food supply chain, illustrated by the German initiative of Rhöngut.

Getting beyond an early lock-in: rebalancing in the De Hoeve initiative. ${ }^{3}$

De Hoeve is a relatively small scale pork supply chain, which includes chain director De Hoeve Ltd owned by the two initiators, 50 pig farmers organized in an association, a slaughterhouse, a meat cutter/wholesaler, and 75 quality butchers operating under the Keurslager hallmark. The initiative started in 1996 in the Dutch province of Brabant but has recently expanded to include farmers and butchers in other Dutch provinces. This initiative is to be situated in the context of the conventional Dutch pork supply chain: a globalized supply chain dominated by large processors and retailers in which price competition within and between chains is extremely fierce and that is subject to strict governmental regulation due to the environmental pollution and animal welfare concerns associated with intensive pig breeding.

De Hoeve started with a range of interconnected novel housing techniques that combined lower construction costs with environmental, food safety, and animal welfare improvements. This novel housing system was designed by a pig farmer. It differed, however, substantially from the official Green Label system. To obtain a permit to build a new housing system and to get access to investment subsidies it was necessary for the farmer to get an environmental license, i.e., the Green Label, for the housing system. With the support of an environmental engineer, the pig farmer succeeded to find an independent institute to test the novel housing system. It turned out that the ammonia emission levels were significantly lower than required by Green Label standards and the housing system received the required environmental license. After the successful recognition of the housing system, the farmer and the environmental engineer became interested in getting an

\footnotetext{
$\overline{3}$ This section is based on Brandsma et al. (2005), Oostindie et al. (2006), and Wiskerke and Roep (2007).
} 
environmental label (Milieukeur) for pork. In the process of applying for this environmental label for pork, the farmer and the engineer established De Hoeve, a limited company with two founders as main shareholders.

De Hoeve's application for an environmental label for pork led the Milieukeur foundation to request the Centre for Agriculture and Environment — an independent research and advisory organization - to develop a set of indicators and standards for pork. This was to be done in close consultation with an advisory committee of relevant stakeholders: environmental organizations, animal welfare organization, research institutes and regional farmers' unions. It was only after extensive debate and negotiations that a list of indicators and standards was approved in May 1998. Five months later De Hoeve pork was officially granted the Milieukeur label.

The next step was to develop the marketing of the pork with Milieukeur. In retrospect, this proved to be the most difficult step. To realize the commercialization of Milieukeur pork De Hoeve contacted the Stichting Agro Keten Kennis (AKK; Foundation Agro Chain Expertise), which coordinated the national program "Added value in pork supply chains." This program offered De Hoeve the opportunity to start a three years project aimed at commercializing their Milieukeur pork. Different chain partners were interested to participate in this project (see Brandsma et al. (2005) for a detailed account). However, the kinds of alliances they were seeking with De Hoeve differed, which resulted in a rather instable network of commercial partners (Van der Schans 2004): several chain partners entered, yet most of them withdrew before the end of the project. According to Hagelaar (2003) the creation of a long lasting stable alliance between these actors was doomed to fail, as their internal organization was fully aligned with the reigning market system, i.e., the spot market. This implied everyday or at most weekly negotiations between different parties about price, quality, and quantities. This institutionalized system of interaction between different parties hampered long lasting collaboration between (and commitments of) these parties involving long term agreements about price, meat quality, quantities, and delivery conditions (Van der Schans 2004).

The opportunities for selling Milieukeur pork improved when De Hoeve met the national association of Quality Butchers (Keurslager). At a meeting of the Keurslager butchers De Hoeve also met wholesaler Hems, who was clearly interested in De Hoeve's pork. This became the start of a close cooperation between De Hoeve, wholesaler Hems, and the Keurslager association. There seemed to be sufficient alignment of interests and expectations among these three parties for a potentially fruitful strategic alliance. Wholesaler Hems delivered to regional Keurslager butchers and foresaw that cooperation with De Hoeve could strengthen its position as preferred supplier of the Keurslager butchers. In addition to wholesaler Hems and the regional Keurslager butchers, De Hoeve also succeeded to enroll slaughterhouse Tomassen in the new alliance. Based on its previous experiences, De Hoeve realized that an important success factor of this new opportunity would be the issue of chain governance. It considered itself as the most appropriate candidate to fulfill this role given its good relations with the association of pig farmers and its growing experience with the organizational aspects of pork supply chains. 
In this new situation De Hoeve became responsible for purchasing pigs and for negotiations with slaughterhouse Tomassen about slaughtering costs. Initially all carcasses were sold to Hems, which means Hems also gets pigs with relatively high fat percentages. As these were more difficult to sell to regional butchers, Hems was only willing to buy carcasses with low fat percentages. However, as slaughterhouse Tomassen was not willing to sell carcasses that did not meet the requirements of Hems (or actually of the Keurslager butchers) De Hoeve needed to find another slaughterhouse for these pigs. It succeeded to sell these pigs to slaughterhouse $D e$ Wit, which sold these carcasses to conventional chains. Having to deal with two slaughterhouses at two different locations implied high costs for logistics for this relatively small scale initiative. Furthermore this situation made it difficult to fulfill prevailing hygiene regulations.

In 2002 De Hoeve replaced their existing slaughterhouses with the Dumeco slaughterhouse in Weert. This slaughterhouse was able sell the carcasses that did not meet the quality criteria of the Keurslager butchers (around 50\% of the total) through its own conventional outlets. However, the contract with Dumeco only lasted two years as the slaughterhouse found that the small amounts of Milieukeur pork it was slaughtering did not fit with its large scale operations. De Hoeve once again had to look for another slaughterhouse and this time contracted Westfort a mid-size slaughterhouse. De Hoeve took this opportunity to further optimize chain governance and organization to further reduce transaction and maintenance costs. They also arranged for pig breeders to be paid a premium when they met the quality criteria required by Hems wholesaler and the Keurslager butchers.

This brief account of the start of De Hoeve shows that the outset of an initiative is a moment when crucial choices are made with regard to the GEM domains, affecting their interrelations and in effect their balancing. In this early stage the initiative gets a setting that will impact on its further evolution. And then it might turn out that the desired evolution of the food supply chain is not tuned to the initial intentions of the initiators, implying a misbalance. This was clearly true in this case: De Hoeve actually started with a focus on environmental certification for a housing system and subsequently for pork. Through the involvement of different civil society organizations and interest groups in defining the environmental certification criteria, the societal embeddedness of the initiative increased. However, the initiators had not seriously considered the marketing and governance aspects. The alliance with the quality butchers was a crucial step in fine tuning both marketing and governance. Nevertheless, the governance of the whole chain remained a problematic issue. It turned out that the initiators could not rely on conventional structures and procedures, but instead had to build a whole new supply chain and management structure from scratch. Different chain partners entered and left the scene, but in the end the initiators succeeded in creating a strategic alliance characterized by mutual dependencies between the actors in the pork supply chain. Simultaneously also the management procedure changed, with De Hoeve taking up the role of chain captain. The story of this initiative shows that a specific setting at the outset can lead to a certain lock-in that hampers the further development of a food supply chain. Overcoming such lock-ins requires fundamental adjustments in and rebalancing of $\mathrm{G}, \mathrm{E}$, and $\mathrm{M}$. 
Remaining in charge while scaling up: rebalancing in the Naturabeef initiative. ${ }^{4}$

NaturaBeef can be traced back to the mid 1970s with the introduction of a suckling cow production system in Switzerland. The organization has grown steadily since its establishment: in 1977 there were 42 producers, by 2004 there were 3,775 producers.

The introduction of a suckling cow system in Switzerland in 1974 was a response to the problems the state run agricultural marketing system was experiencing with an oversupply of milk, while much beef was being imported. This led the state to search for other grassland-based activities to provide farmers with an alternative to dairy production. This resulted in a three years research project to test (and improve) a suckling cow system on 30 pilot farms. After three years the 30 participating producers were convinced of the advantages of this production system and sought assistance to create an organization to carry the work forward on a commercial basis. This resulted in the establishment of the Swiss Association of Suckling Cow Breeders (ASVNM).

By 1980 the ASVNM had attracted 118 members. However, at that time the quality of the product was not yet recognized and had not found a place on the market. The first strategic marketing act was to give the product its name NaturaBeef and a logo and communicate naturalness as image. This paved the way for communicating the special qualities of the beef to consumers. At the outset, most of the meat was sold directly over the farm gate and some through local butchers. It was not very long until the ASVNM entered into its first strategic alliance with BELL, an independent butchery chain with its own high street trademark and shops in several Swiss towns, who started selling NaturaBeef meat to its customers. ASVNM entered into a non-written agreement with BELL. Soon afterwards regional branches of Coop — one of the two leading Swiss retailers-also started selling NaturaBeef in their outlets. At this time ASVNM entered into strategic alliances with two cattle trading companies-Viegut AG and VIANCOgiving these two companies exclusive rights to trade in NaturaBeef. Together with the agreements with BELL and Coop, this gave ASVNM a relatively secure and stable market, a communication channel to consumers and satisfactory prices for the meat. In turn, this resulted in ASVNM attracting more members: between 1980 and 1990 the number of producers increased from 118 to 750 . With the increase in the number of members it became increasingly difficult to organize meetings, so the ASVNM decided to create nine regional groups. This decentralized and democratic structure assured that the members could participate in the meetings at regional level and feel a sense of ownership of the association and the brand.

A crucial stage in the further upscaling of NaturaBeef occurred in the early 1990s. The most important outlets for NaturaBeef were undergoing a consolidation process with regional branches of Coop unifying many of their internal services and BELL becoming an integral part of the Coop group. This meant that ASVNM was increasingly dependent on one customer (i.e., Coop) for its meat sales. Coop imposed a level of exclusivity on the label, mainly to assure that its main rival-

\footnotetext{
$\overline{4}$ This section is based on Damary (2006).
} 
Migros-did not have access to it. This agreement permitted farmers to continue to sell NaturaBeef directly and through the local butcher shops that had already been selling NaturaBeef before the agreement was signed. However, it did give Coop exclusive rights within the retailing sector. Soon after that Coop created its own new environmental line named Coop NaturaPlan as a means to address the growing consumers' demand for "natural products." NaturaBeef served as the eye catcher of Coop NaturaPlan. This reinforced the mutual dependency between ASVNM and Coop. However, this reliance on one major sales outlets combined with the increase in number of producers, was identified as a long term risk by ASVNM. To stay in control and maintain unity within the organization and discipline among its members, ASVNM decided to introduce a "sales license" for all those trading or selling NaturaBeef. This license gave ASVNM much more control over the product flow and quantities as in effect it extended the controls from the ASVNM to not only the farmers but also the traders, abattoirs, butchers, and shops including Coop. All those involved in the NaturaBeef supply chain, be they farmers doing direct sales, traders, butchers shops, or large retailers, had to buy an annual license and report on quantities bought and sold. This license became the basis for establishing a traceability system based on product flows. With this licensing system, ASVNM assured that they remained united in their negotiating position and had better knowledge and control of volumes.

The story of NaturaBeef is a clear example of the importance of rebalancing governance, embedding, and marketing while scaling up. Scaling up often entails the involvement of a (strong) marketing partner, e.g., a retailer, and the creation of a new alliance. In the case of NaturaBeef this is illustrated by the cooperation with BELL and later Coop. Such a strong partner will negotiate some level of control with regard to marketing, implying that initiators in turn may lose some control with regard to marketing issues and thus ultimately also with regard to chain governance. This also appeared to happen in the case of Naturabeef. However, this decision to issue a sales license is an outstanding example of initiators succeeding to safeguard their stake by adjusting the governance of the food supply chain. As we learned from many other cases, the danger of scaling up is that an improper balancing might fire back at the initiators when the new partner cannot meet the expectations or fails at the cost of the prime initiators (see e.g., Roep (2000) for a detailed account of the failure of a regional high quality cheese supply chain).

Product diversification through regional embedding: rebalancing in the Tegut-Rhöngut initiative. ${ }^{5}$

The foundation of the family-owned retailer Tegut leads back into the year 1947. Tegut has two main particularities: at first, its strong quality-orientated policy, secondly, its strong position in a specific region in the very middle of Germany. The Tegut-philosophy is based on high quality food, reflected in the slogan "Tegut... gute Lebensmittel" (Tegut-good food). This commitment to quality was put up by the founder of Tegut, is continued by his son, and will be continued by his grandson.

\footnotetext{
5 This section is based on Schaer et al. (2006).
} 
The focus on quality in the company's management and in its external communication is somewhat in contrast to the German retail sector, where, since the 1950s, prices are always in the center of strategic and operational action. As a coherent consequence of its quality commitment, Tegut emphasizes ecological and social values. It has a relatively high percentage of organic products in the assortment.

One facet of the search for optimal quality is that it has led the company to develop its own processing facilities. Tegut established its own meat processing facility in the 1970s, which has been processing organic meat since 1986, and started producing organic bread in 1992, when it launched one of Germany's biggest organic bakeries. Tegut has also created a dedicated organic trading and packaging company and a chain of specialized organic food stores, both trading under the same name-Alnatura. While this company is, at least formally, independent from Tegut, business relations between the two are very close. As a processor and retailer, Tegut is a natural "channel captain" as large parts of the channel belong to the company.

The most recent example of this quality-orientated integrating policy was the development of the Rhöngut brand and the development of a new production site, where the products of this brand, special meat and sausage products, are processed. Rhöngut links organic and regional produce by using special, innovative, and typical processing methods, such as dry cured hams and sausages from beef and meat. Tegut launched this initiative with the aim of supplying high quality organic regional meat products to its own supermarkets and to Alnatura organic food stores. The name Rhöngut is a combination of Rhön, a specific landscape and the gut of Tegut. The slogan "Rhöngut-Naturgereift in Rhöner Hohenluft" (naturally ripened in the mountain air) embodies regional identification, natural production and the healthy environment. Thus the brand draws on territorial and local resources and is representative of the main values of Tegut in relation to regional commitment and sustainable development. The choice of the term Rhön can be seen as an attempt by Tegut to better illustrate its regional engagement. The Rhön, a mountainous area with extensively used grasslands and woods is a very distinctive and well known landscape, part of which is protected as a UNESCO Biosphere Reserve. As such it embodies several issues that are central to Tegut's concerns: a healthy environment and traditional, sustainable agriculture.

The initiative was set up in a very active rural area with a high concentration of organic farmers, and where social and ecological initiatives are well-developed. It is an area where extensive sheep and cattle grazing have been practiced for generations. Farmers had converted to organic farming relatively early, as the change reduced the cost of farming. Many farms have also built up a network for direct sales, and some production systems are based on alternative land use concepts. This background provided good conditions for developing a retail-led enterprise that was grounded in a sustainable philosophy. It provided both a sympathetic local environment and a pre-existing level of consumer awareness about "Rhön products."

Thus, Tegut managers were able to draw on four factors to help ground the success of Rhöngut: the image of the region, the particularity of its agriculture, the dynamic network of existing sustainability initiatives, and their own experience in 
processing and marketing of organic meat and beef products. By choosing the method of dry curing, they added a fifth one: innovative processing techniques. The innovation of creating a range of dry-cured, air-dried products, like the ham and sausage specialities from southern European countries fitted well in the mountainous area of the Rhön, with its dry and windy climate. As a next step, Tegut invested in a processing plant, situated within the Rhön area.

Tegut's initiative led to the establishment of a new association of 30 farmers involved in preserving extensive cattle breeds and traditional grazing practices. They mostly produce for Tegut, although there is no collective contract or formal collaboration. All of the more than 40 farmers who produce for Tegut are in individual contact with the company over issues such as production volumes, quality, delivery dates, conditions, and payments. From the very outset Rhöngut's products were a great success. The pre-sliced ham and sausages achieve a premium of up to $90 \%$ above comparable conventional products. Their green packaging evokes high quality, the Rhön landscape, and organic production and these factors, together with the company's reputation, all contribute to this additional value added.

With impressive growth in demand, a new production plant had to be built, more staff employed, and a growing number of farmers are producing for the initiative. However, the rapid success of the brand and rapid growth in production volumes, also gave rise to supply problems. These arose not only because of the limited volume of regional production, but also because of an ever increased effort involved in co-ordinating, and maintaining communication lines along the supply chain. The principle of dealing with all of the farmers individually, derived from the classical behavior of a retailer channel-captain towards its suppliers, ran up against its limits. The Tegut managers are currently looking for new ways of communicating with their supply base, and seeking to encourage co-operation between farmers. In doing so, they accept the risk of strengthening the farmers' negotiation position. This potential disadvantage is offset by the efficiencies to be gained from a better knowledge transfer from Tegut to farmers over meat quality and the improvements that can be gained in terms of traceability.

The Rhöngut case is a clear example of the issues at stake when seeking to diversify the range of products of a well established food supply chain, such as Tegut, by opting for more distinctiveness through local embedding of new food products. In this case regional embedding is a marketing strategy-clearly illustrated by the impact of the packaging of Rhöngut products. However, in order to work properly, it is not only a matter of marketing regional embeddedness of products. It also requires changes in chain governance. Tegut's efforts to set up a producers' association, even at the expense of losing some of its control over negotiation power, is a typical example of that.

\section{By Way of Conclusion}

Finding and maintaining a proper balance between governance, embedding, and marketing in the development of food supply chains is a key to success. As the examples presented and discussed in this article highlight, changes in one domain 
have to be completed with changes in other domains to safeguard a proper balance. As food supply chains in development are continuously subject to all kinds of intended and unintended changes with desirable as well as undesirable outcomes, safeguarding a proper dynamic balance is like dancing on a chord. The "dancing" is the continuous evaluation of changes and its consequences and an ongoing reflection on what a "proper" balance is and how it can be achieved and maintained accordingly. There is no recipe or blueprint for the "dancing" nor for what a "proper balance" is or ought to be. With the GEM framework that we presented we also do not have the intention to provide something like a recipe or blueprint. The GEM framework is merely a reflexive tool for practitioners and their supporters, one that can help them to position themselves, develop a clear strategy, find the right allies, develop their skills, and build the capacities that they need. As a reflexive tool the GEM framework can not only help practitioners to find the right road, but also to travel along it well equipped (Knickel et al. 2006).

Furthermore, the GEM framework allows for a better understanding of how sustainable chains are constructed. By using this framework it is possible to better conceptualize different types of alternative food supply chains at different stages of their development. It posits that a food supply chain development trajectory always involves a combination of governing, embedding, and marketing $(\mathrm{G}+\mathrm{E}+\mathrm{M})$. For initiatives that aim to strengthen the bargaining power and commercial position of farmers in the food supply chain, the focus of related research work should be on the development of the most suitable forms of chain governance. Key questions are how to mobilize strategic alliances, how to build strong support networks that create a protected space, or niche, for experimenting and learning, and what are the most suitable governance configurations to avoid an expropriation of control. For initiatives focusing on product diversification the emphasis is usually on improving the commercial performance of an established organizational configuration. The key questions, then, are those of how to develop and market more distinctive products (or a range of products) alongside existing, well established ones. As the Rhöngut case illustrated such key questions are related to new strategies for improving the local embeddedness of a (range of) products and to aspects of chain governance.

The GEM framework also has great relevance as a policy tool for politicians and policy makers. It can assist them in improving strategic choices over what needs enhancing and in developing better and more targeted policy instruments. Policy is about making choices: who and what to support, and how to provide this support in the most effective way. In this respect it is important to note that support is not only financial, but can also come in other forms. We can identify a number of different types of support: financial (e.g., through investment or start-up finance); marketing, information and public relations; advocacy and public legitimization of the initiative, brokering; training and consulting; and technical and legal support for innovative and experimental approaches. Finally, it is not only public bodies that can act as a source of support; social organizations, communities, individuals, and (actual or potential) trading partners are also potential sources of support.

The question of how to provide effective support in the most efficient way comes back to issues of identifying the type of support needed, and providing it in the right amount and at the right time. Being aware of the crucial dimensions involved in the 
construction and development of food supply chains and of the need for different kinds of support at different stages of development can help to improve the targeting of support.

To end this paper, we want to briefly reflect on how Actor-Network Theory (ANT) has inspired our empirical research. ANT and more in particular the notion of translation cycles, made us sensible "for the messy practices of relationality and materiality of the world" (Law 2009) and enabled us to "tell stories about how relations assemble or don't" (Ibidem), of the importance of non-human entities in the assemblage of more stable and durable food networks, how these networks of relations evolve, pass points of no return, or just take turns. ANT can indeed be a useful "toolkit for telling interesting stories about, and interfering in, those relations" (Ibidem). We are, however, aware that we were only capable of telling three slightly superficial stories, highlighting only some aspects of the construction of socio-material relations and the ways in which these relations can become more stable and durable. For a more detail account we refer to the case study reports on www.sus-chain.org.

Acknowledgments The authors are grateful to Pieter Jan Brandsma and Henk Oostindie for the description and analysis of De Hoeve, to Peter Damary for the description and analysis of NaturaBeef, and to Burkhard Schaer, Claudia Strauch, and Karlheinz Knickel for the description and analysis of Tegut and Rhöngut. We want to thank the entire SUS-CHAIN consortium for their critical though supportive comments on the conceptual framework. The research on which this paper is based was financed by the European Commission (contract no. QLK5-CT-2002-01349). The views expressed in this article are those of the authors and do not necessarily reflect those of the European Commission. The authors also wish to express their gratitude for the helpful comments of the reviewers of a previous version of this paper.

Open Access This article is distributed under the terms of the Creative Commons Attribution Noncommercial License which permits any noncommercial use, distribution, and reproduction in any medium, provided the original author(s) and source are credited.

\section{References}

Berger, G. (2003). Reflections on governance: power relations and policy making in regional sustainable development. Journal of Environmental Policy and Planning, 5, 219-234.

Brandsma, P., Oostindie, H., \& Roep, D. (2005). De Hoeve pork supply chain-case study report. http://www.sus-chain.org/results/WP5/NL\%20De\%20Hoeve\%20-\%20Final\%20report.pdf. Accessed 4 August 2009.

Brunori, G., \& Wiskerke, J. S. C. (2004). SUS-CHAIN case study methodology. http://www.sus-chain.org/ results/WP4/WP4\%20SUS-CHAIN\%20case\%20study\%20methodology.pdf. Accessed 4 August 2009.

Callon, M. (1986). Some elements of a sociology of translation: Domestication of the scallops and the fishermen of St. Brieuc Bay. In J. Law (Ed.), Power, action and belief: A new sociology of knowledge? (pp. 196-233). London: Routledge and Kegan Paul.

Damary, P. (2006). Anticipating the implications of scaling up: Natura Beef. In D. Roep \& J. S. C. Wiskerke (Eds.), Nourishing networks: Fourteen lessons about creating sustainable food supply chains (pp. 69-78). Doetinchem: Reed Business Information.

Fenwick, T. (2010). Re-thinking the "thing": Sociomaterial approaches to understanding and researching learning in work. Journal of Workplace Learning, 22(1/2), 104-116.

Goodman, D., \& DuPuis, E. M. (2002). Knowing food and growing food: Beyond the productionconsumption debate in the sociology of agriculture. Sociologia Ruralis, 42, 5-22. 
Granovetter, M. (1985). Economic action and social structure: The problem of embeddedness. American Journal of Sociology, 91(3), 481-510.

Hagelaar, G. (2003). Strategie, samenwerking en structuur: Een varkensvleesketen in transitie. Wageningen: Wageningen University-Management Studies Group.

Hess, M. (2004). 'Spatial' relationships? Towards a reconceptualization of embeddedness. Progress in Human Geography, 28(2), 165-186.

Kirwan, J. (2004). Alternative strategies in the UK agro-food system: Interrogating the alterity of farmers' markets. Sociologia Ruralis, 44, 395-415.

Kirwan, J., Slee, R. W., Foster, C., \& Vorley, B. (2004). Macro-level analysis of food supply chain dynamics and diversity in Europe-synthesis report. http://www.sus-chain.org/results/WP2/ suschain\%20deliverable\%2010\%20(wp2\%20synthesis\%20report).pdf. Accessed 3 August 2009.

Knickel, K., Jahn, G., Roep, D., \& Wiskerke, J. S. C. (2006). Enhancing sustainable food supply chain initiatives. In D. Roep, J. S. C. Wiskerke, et al. (Eds.), Nourishing networks: Fourteen lessons about creating sustainable food supply chains (pp. 165-175). Doetinchem: Reed Business Information.

Lang, T. (2010). Crisis? What crisis? The normality of the current food crisis. Journal of Agrarian Change, 10(1), 87-97.

Law, J. (1992). Notes on the theory of the actor-network: Ordering, strategy, and heterogeneity. Systems Practice, 5, 379-393.

Law, J. (2009). Actor-network theory and material semiotics. In B. S. Turner (Ed.), The newblackwell companion to social theory (pp. 141-158). Chichester: Wiley-Blackwell.

Marsden, T., Murdoch, J., \& Morgan, K. (1999). Sustainable agriculture, food supply chains and regional development: editorial introduction. International Planning Studies, 4, 295-301.

Murdoch, J. (2000). Networks-A new paradigm of rural development? Journal of Rural Studies, 16, 407-419.

Murdoch, J., Marsden, T., \& Banks, J. (2000). Quality, nature \& embeddedness: Some theoretical considerations in the context of the food sector. Economic Geography, 76, 107-125.

Oostindie, H., Brandsma, P. J., \& Roep, D. (2006). Creating space for change: De Hoeve pork supply chain. In D. Roep \& J. S. C. Wiskerke (Eds.), Nourishing networks: Fourteen lessons about creating sustainable food supply chains (pp. 27-38). Doetinchem: Reed Business Information.

Renting, H., Marsden, T. K., \& Banks, J. (2003). Understanding alternative food networks: Exploring the role of short food supply chains in rural development. Environment and Planning A, 35, 393-411.

Roep, D. (2000). Vernieuwend werken: Sporen van vermogen en onvermogen. $\mathrm{PhD}$ thesis, Wageningen University, Wageningen.

Roep, D., \& Wiskerke, J. S. C. (2004). Reflecting on novelty production and niche management in agriculture. In J. S. C. Wiskerke \& J. D. van der Ploeg (Eds.), Seeds of transition: Essays on novelty production, niches and regimes in agriculture (pp. 341-356). Assen: Royal Van Gorcum.

Roep, D., \& Wiskerke, J. S. C. (2006). Nourishing networks: Fourteen lessons about creating sustainable food supply chains. Doetinchem: Reed Business Information.

Roep, D., \& Wiskerke, J. S. C. (2007). Constructing sustainable regional food networks: A grounded perspective. In W. Zollitsch, C. Winkler, S. Waiblinger, A. Haslberger, et al. (Eds.), Sustainable food production and ethics (pp. 174-179). Wageningen: Wageningen Academic Publishers.

Schaer, B. (2001). Regionales gemeinschaftsmarketing für öko-lebensmittel: Dargestellt am beispiel der konzeption des zeichens "oko-qualität, garantiert aus Bayern”. PhD thesis, Technical University, München.

Schaer, B., Knickel, K., \& Strauch, C. (2006). Regional embedding as a marketing strategy: Tegut supermarket and Rhöngut meat processing. In D. Roep \& J. S. C. Wiskerke (Eds.), Nourishing networks: Fourteen lessons about creating sustainable food supply chains (pp. 123-134). Doetinchem: Reed Business Information.

Schaer, B., \& Sirieix, L. (forthcoming). How sustainable food supply chains re-invent marketing. In J. S. C. Wiskerke, J. Kirwan, \& G. van Huylenbroeck (Eds.), Sustaining food supply chains: Grounded perspectives on the dynamics and impact of new modes of food provision. London: Ashgate.

Sonnino, R. (2007). Embeddedness in action: Saffron and the making of the local in southern Tuscany. Agriculture and Human Values, 24, 61-74.

Sonnino, R., \& Marsden, T. K. (2006). Beyond the divide: Rethinking relationships between alternative and conventional food networks in Europe. Journal of Economic Geography, 6, 181-199.

Van der Ploeg, J. D. (2006). Agricultural production in crisis. In P. Cloke, T. Marsden, \& P. Mooney (Eds.), Handbook of rural studies (pp. 258-277). London: Sage Publication. 
Van der Ploeg, J. D. (2010). The food crisis, industrialized farming and the imperial regime. Journal of Agrarian Change, 10(1), 98-106.

Van der Schans, J. W. (2004). Milieukeur varkensvlees de keten door. Den Haag: Landbouw Economisch Instituut.

Watts, D. C. H., Ilbery, B., \& Maye, D. (2005). Making reconnections in agro-food geography: Alternative systems of food provision. Progress in Human Geography, 29, 22-40.

Wiskerke, J. S. C., \& Roep, D. (2007). Constructing a sustainable pork supply chain: A case of technoinstitutional innovation. Journal of Environment Policy and Planning, 9, 53-74.

Wiskerke, J. S. C., \& Van der Ploeg, J. S. C. (2004). Seeds of transition: Essays on novelty production niches and regimes in agriculture. Assen: RoyalVan Gorcum. 